\title{
An Alternative Approach Wound Healing Field with Polypodium Vulgare
}

\section{Polypodium Vulgare ile Yara İyileşme Alanına Alternatif Bir Yaklaşım}

\author{
Sebnem Batur $\odot$, Sule Ayla $\odot$, Ayse Arzu Sakul $\odot$, Mehmet Evren Okur $\odot$, Ayse Esra Karadag $\odot$, \\ Benay Daylan $\odot$, Ekrem Musa Ozdemir $\odot$, Nuray Kepil $\odot$, Mehmet Yalcin Gunal $\odot$
}

Ethics Committee Approval: This study approved by the Istanbul Medipol University Ethics Committee for Animal Researchs, 11 December 2019, 2019/89.

Conflict of interest: The authors declare that they have no conflict of interest.

Funding: None.

Informed Consent: Not Applicable.
Cite as: Batur S, Ayla S, Sakul AA, et al. An alternative approach wound healing field with polypodium vulgare. Medeni Med J. 2020;35:315-23.

\begin{abstract}
Objective: In this study, we examined the effects of Polypodium vulgare L. (Polypodiaceae) as a candidate to be used for wound healing scarred area. We investigated the antibacterial, and antioxidant activity of $P$. Vulgare on both in vivo, and in vitro wound healing using an excisional wound model in mice

Method: We used 32 Balb-c mice equally divided into four groups: Group 1 control, Group 2 vehicle, Group 3 Polypodium vulgare, and Group 4 Centella asiatica extract (CAE). All treatments were applied topically once in a day. The scar area, percentage wound closure and epithelization time were measured. PDGF, VEGF, and collagen immunohistochemical staining were used for evaluation.

Results: CAE and P. vulgare extract groups were observed to be more effective than the control and vehicle groups in terms of new vascular, epidermal and granulation tissue organization. $P D G F, V E G F$, and collagen immunohistochemical staining was stronger in the P.vulgare extract and CAE groups compared to the control and vehicle groups. In the P. vulgare and CAE groups, PDGF staining intensity was stronger than the control and vehicle groups, but VEGF and collagen staining in $P$. vulgare group was not different from the control group.

Conclusion: $P$. vulgare had an effect on the injured area by regenerating the epidermis and increasing vascularization. $P$. vulgare extract with known antioxidant, and antimicrobial activities may be helpful as a supportive treatment in wound healing.
\end{abstract}

Keywords: Wound healing, polypodium vulgare, antioxidant

öz

Amaç: Bu çalışmada Polypodium vulgare L. (Polypodiaceae), yara iyileşme adayı olma potansiyeli açısından değerlendirildi. Farelerde eksizyonel bir yara modeli kullanılarak hem in vivo hem de in vitro yara iyileşmesinde P.vulgare'nin antimikrobiyal ve antioksidan aktivitesini araștırdık. Yöntem: Eşit olarak dört gruba ayrılmış toplam 32 Balb-c faresi kullandık; Grup 1 kontrol, grup 2 taşıyıcı grup 3 Polipodyum vulgare, grup 4 Centella asiatica özütü (CAE). Tüm tedaviler topikal olarak günde bir kez uygulandı. Yara izi alanı, yara kapanma yüzdesi ve epitelizasyon süresi ölçüldü. İmmünhistokimyasal değerlendirmede PDGF, VEGF ve kollajen boyaları kullanıldı.

Bulgular: CAE ve P. vulgare ekstrakt gruplarının yeni vasküler organizasyon, epidermis ve granülasyon doku organizasyonu açısından kontrol ve taşıyıcı gruplarından daha etkili olduğu gözlenmiștir. PDGF, VEGF ve kollajen immünohistokimyasal boyama, P.vulgare ekstraktı ve CAE gruplarında kontrol ve taşıyıcı gruplarına göre daha kuvvetliydi. P. vulgare ve CAE grubunda PDGF boyama yoğunluğu, kontrol ve taşıyıcı gruplarından daha kuvvetliydi, ancak $P$. vulgare grubundaki VEGF ve kollajen boyama, kontrol grubundan farklı değildi.

Sonuc:

P. vulgare yara iyileşmesini ve granülasyon dokusunu, epidermal rejenerasyonu ve anjiyogenezi arttırdı. Antioksidan ve antimikrobiyal aktiviteleri ile bilinen P. vulgare ekstraktı, yara iyileşmesini desteklemek için yararlı olabilir.

Anahtar kelimeler: yara iyileşmesi, polypodium vulgare, antioksidan
Received: 27 July 2020

Accepted: 21 September 2020 Online First: 25 December 2020

Corresponding Author:

S. Batur

ORCID: 0000-0001-6577-8970 Istanbul University-Cerrahpasa,

Cerrahpasa Faculty of Medicine,

Department of Pathology,

Istanbul, Turkey

batursebnem@gmail.com

ORCID: 0000-0001-5494-6422 Istanbul University-Cerrahpasa Faculty of Medicine, Departme Istanbul, Turkey

ORCID: 0000-0003-2143-5268 B. Daylan

ORCID: 0000-0002-8302-1127 Istanbul Medipol University, Faculty of Medicine Department of Histology and Embryology, Istanbul, Turkey

A.A. Sakul ORCID: 0000-0002-9354-0000
Istanbul Medipol University, Faculty of Medicine, Istanbul, Department of Medical Pharmacology, Istanbul, Turkey

M.E. Okur

ORCID: 0000-0001-7706-6452 University of Health Sciences, Faculty of Pharmacy, Department of Pharmacology, Istanbul, Turkey

A.E. Karadag ORCID: 0000-0002-3412-0807 Istanbul Medipol University, Faculty of Pharmacy, Department of

Pharmacognosy, Istanbul, Turkey

E.M. Ozdemir ORCID: 0000-0001-9416-7757 Istanbul Medipol University, Department of Animal Facility, Istanbul, Turkey

M.Y. Gunal ORCID: 0000-0001-7702-2441 Alanya Alaaddin Keykubat University, Faculty of Medicine, Department of Physiology, Alanya, Turkey 


\section{INTRODUCTION}

Wound healing is a complicated period both for skin and tissues especially after an injury. Epidermis and dermis in the undamaged tissue is a protective barrier against external influences. When the barrier breaks, some repair processes are activated ${ }^{1}$. Wound healing is of great clinical importance since untreated wounds can be fatal ${ }^{2,3}$. It was reported that wounds, especially chronic ones can be quickly colonized by both Grampositive or negative bacteria, fungus and even viruses $^{2,4}$. Therefore, doctors recommend topical use of antibiotics to prevent unexpected effects such as sepsis and bacteremia. For wound healing and management, various pharmaceutical products can be used ${ }^{4}$. Traditional medicine is full of knowledge that has been developed through generations in various societies. Traditional medicine approaches are based upon natural products from plants, animals, and minerals. African and Asian communities have used plants for primary health care ${ }^{5}$. Herbal medicines include sections of plants, different plant parts, their combinations, or plant extracts. Plants are used frequently by medical practitioners in wound healing ${ }^{6}$. From past to present, various plants have been used as wound healing agents such as Laurocerasus sp., Capparis sp., and Prunus spinosa ${ }^{4,7}$.

In this study, Polypodium vulgare L. (Polypodaceae) is evaluated for its potential as a wound healing candidate. Polypodium vulgare L. (P. vulgare) is a plant known and have been used by people since ancient times. Its rhizomes are more wellknown and are included in some foods as sweetening agents ${ }^{8,9}$. In ethnobotanical medicine the plant is used for its antitussive and diuretic properties ${ }^{10}$. Infusion prepared from its roots is used in abdominal pain and inflammatory conditions. In addition, the pharmacological activities of the plant on the liver and lung are also known. It has also antioxidant, anticholinesterase, antimicrobial, antiviral, antiepileptic, antipyretic, and analgesic properties ${ }^{11-14}$. P. vulgare is used in tradi- tional medicine as an expectorant to treat cough and pertussis ${ }^{15}$. Centella asiatica extract (CAE) is a molecule that facilitates the repair process of the wound tissue and has been shown to exhibit antimicrobial activity ${ }^{16}$. For this reason, it has been preferred as a reference molecule in many studies including this one. We investigated the effects of P.vulgare on excisional wound healing in mice.

\section{MATERIAL and METHODS}

\section{Preparation of Extract}

P. vulgare aerial parts were collected from Belgrade forests, Istanbul, in 2018. Herbal ingredient was identified (specimen no. IMEF: 1068) and stored. The airdried herb was soft powdered in alcohol for 24 hours. Following permeation and vaporization (Heidolph, Germany), gel formulations were prepared by the methanol extract

\section{Antioxidant Activity in Vitro}

\section{- 2,2-diphenyl-1-picrylhydrazyl (DPPH) scaven- ging}

DPPH - was used to determine the total antioxidant capacity ${ }^{17}$. The reaction mix contained 100 $\mu M \mathrm{DPPH}^{\circ}$ in methanol and P. vulgare extract. After $30 \mathrm{~min}$, UV spectrophotometer (UV-1800, Shimadzu, Japan) read absorbance value at 517 $\mathrm{nm}$. The scavenging activity was calculated as the percent radical reduction as follows:

$\mathrm{DPPH} \cdot \mathrm{RSA} \%=[$ (Absorbance control - Absorbance test sample) / Absorbance control)] x 100

\section{- 2,2-Azino-bis 3-ethylbenzthiazoline-6-sulfo- nic acid (ABTS) scavenging}

Re and co-workers' protocol was used for obtaining P. vulgare methanol extract ${ }^{18}$. Potassium persulfate and ABTS - blend was kept at room temperature in a dark room for $16 \mathrm{~h}$ prior to its use. The $734 \mathrm{~nm}$ was its absorbance measure. The study 
was repeated three times. For negative controls: ethanol, and positive controls: Trolox were used ${ }^{4}$. The absorbance of the extract obtained was measured as follows:

ABTS - RSA \% $=[$ (Absorbance control - Absorbance test sample) / Absorbance control)] x 100

Antioxidant reading outcomes were studied comparatively with standard reference substances such as ascorbic acid and Trolox.

\section{Antimicrobial Activity in Vitro}

Broth microdilution assay was used for extract specification defined by the Clinical and Laboratory Standards Institute (2006) for minimum inhibitory concentrations (MIC). MIC is the lowest concentration of an antimicrobial agent that prevents growth of an organism.

Staphylococcus aureus ATCC 6538, Enterococcus faecalis ATCC 29212, Escherichia coli NRLL B-3008, and Pseudomonas aeruginosa ATCC 10145 strains were grown in Mueller Hinton Broth (MHB, Merck, Germany) at $37^{\circ} \mathrm{C}$ in aerobic conditions for $24 \mathrm{~h}$. All microorganisms were standardized to $1 \times 108 \mathrm{CFU} / \mathrm{mL}$ using McFarland No: 0.5 in sterile saline $(0.85 \%)$. A modified microdilution assay was used to establish the antimicrobial action of the sample. Dimethylsulfoxide (DMSO) was used to prepare the stock solution.

\section{Preparation of Polypodium Vulgare Extract Gel Formulation}

The gel of the extract was formulated with hydroxypropyl cellulose gel. For preparing the gel, hydroxypropyl cellulose (2\%) was dissolved in distilled water for 24 hours, and then the P. vulgare extract $(5 \%)$ was added, and the blend was stirred slowly.

\section{In Vivo Experiments}

\section{- Experimental Animals}

Balb-c mice (25-28 g) were used in the study. The mice were hosted in regular cages with food and water intake ad libitum, at room temperature $\left(24^{\circ} \mathrm{C}\right)$, with artificial light from 7.00 am to 7.00 pm. Before experiments, ethical clearance approval was obtained from the Local Ethics Committee (No: E.65386-89). During the experiments, the animals were cared for according to the ethical rules.

\section{- Wound formation protocols and animal groups}

The experimental animals were divided into four groups within 8 animals per group;

Group 1: Control group (with sterile saline).

Group 2: Vehicle group (no drug content)

Group 3: Polypodium vulgare extract gel group.

Group 4: Centella asiatica extract (CAE) reference molecule.

Mice were anesthetized intraperitoneally with a combination of $80-100 \mathrm{mg} / \mathrm{kg}$ ketamine and 10 $\mathrm{mg} / \mathrm{kg}$ xylazine intraperitoneally. Two excisional wound tissues were formed using a $5 \mathrm{~mm}$ biopsy apparatus on the left side of the midline in the shaved back region, one $\mathrm{cm}$ apart from each other and $1.5 \mathrm{~cm}$ away from the midline. Treatments were applied to the wounds for ten days.

\section{- Macroscopic Assessment}

For score healing of the wound, photographs were taken at days 0 and 10 . The surface areas were measured with the Image J program. After then, wound healing rates were calculated by the formula given in the literature ${ }^{19}$.

\section{- Histological Assessment}

On the $10^{\text {th }}$ day, the animals were sacrificed and the scar tissue was removed. A $10 \%$ neutral formalin was used for fixation. After that, wound samples were dehydrated in ethanol series, cleared in toluene, and embedded in paraffin. Five $\mu \mathrm{m}$ thick 
sections were taken on glass slides and stained with hematoxylin-eosin ( $\mathrm{HE})$, immunohistochemical stains (vascular endothelial growth factor (VEGF) (Santa Cruz sc-7269), Collagen (COL1A1) (Santa Cruz sc-293182), and Platelet Derived Growth Factor (PDGF-A) (Santa Cruz sc-9974)).

The scoring system defined by Galeano et al. was used for the histological evaluation of wound healing ${ }^{20}$. For epidermal organization; Score 1: weak epidermal tissue organization $\geq 20 \%$ of the tissue, Score 2: incomplete epidermal tissue organization $\geq 40 \%$ of the tissue, Score 3 : moderate epithelial tissue organization $\geq 60 \%$ of the tissue, Score 4: complete epidermal tissue organization $\geq$ $80 \%$ of the tissue. For the thickness of the granulation tissue; Score 1: weak granulation layer, Score 2: moderately dense granulation layer, Score 3: dense granulation layer, Score 4 : very dense granulation layer.

For angiogenesis; Score 1: one to two vessels/ site, Score 2: few neovascularization (3-4/site), Score 3: newly formed capillary vessels (5-6/site) and Score 4 describes newly formed and normal appearing capillary vessels ( $>7 /$ site).

The semiquantitative method was used for the immunoreactivity of immunohistochemical stain. Five randomly selected fields were evaluated and averaged. Score 0: No staining, Score 1: Poor staining, Score 2: Moderate staining, and Score 3: Strong staining 21.

\section{- Statistical analysis}

For statistical analysis, a standard software package (SPSS 20 for Windows, SPSS Inc., Chicago, IL, USA) was used. Differences between groups were analyzed by one-way ANOVA test, followed by the least significant differences tests. All values were given as mean \pm S.E.M. P values values less than 0.05 were considered significant.

\section{RESULTS}

\section{Antioxidant Activity}

Antioxidant activity of P. vulgare extract is summarized in Table 1. It can be said that the extract has a moderate antioxidant capacity compared to the ones used as standard substances. As a result of the experiments, the antioxidant effect of the extract was revealed, and the antioxidant capacity is thought to be effective in the wound healing.

Table 1. ABTS and DPPH radical scavenging activities of $P$. vulgare methanol extract $(\mathrm{IC} 50 \pm \mathrm{SD}(\mathrm{mg} / \mathrm{mL})$.

\begin{tabular}{lll}
\hline & Extract IC $_{\mathbf{5 0}}(\mathbf{m g} / \mathbf{m L})$ & Standards IC $_{\mathbf{5 0}}(\mathbf{m g} / \mathbf{m L})$ \\
\hline ABTS & $3.25 \pm 0.03$ & $0.034 \pm 0.001$ (Trolox) \\
DPPH & $2.13 \pm 0.04$ & $0.009 \pm 0.002$ (Ascorbic acid)
\end{tabular}

*Statistically significant compared to control, $p<0.05$.

\section{Antimicrobial Activity}

The antimicrobial activity of P. vulgare extracts is showed in Table 2 . While the P. vulgare extracts were found to be most sensitive against $S$. aureus; $P$. aeruginosa and $E$. coli were found to be resistant at tested concentrations $(10 \mathrm{mg} / \mathrm{mL})$. MIC value of P. vulgare methanol extract of 0.625 $\mathrm{mg} / \mathrm{mL}$ against $\mathrm{S}$. aureus was determined.

Table 2. MIC values of P. vulgare MeOH extract on tested concentration (MICs in $\mathrm{mg} / \mathrm{mL}$ ).

\begin{tabular}{|c|c|c|c|c|}
\hline & $\begin{array}{l}\text { E. } \\
\text { coli }\end{array}$ & $\begin{array}{l}\text { S. } \\
\text { aureus }\end{array}$ & $\begin{array}{l}\text { E. } \\
\text { faecalis }\end{array}$ & $\begin{array}{l}\text { P. } \\
\text { aeruginosa }\end{array}$ \\
\hline P. vulgare extract & - & 0.625 & 1.25 & - \\
\hline Tetracycline & 0.016 & 0.025 & 0.016 & 0.016 \\
\hline
\end{tabular}

\section{Macroscopic wound healing}

Figure 1 exhibited the percentage of macroscopic wound healing rates. On day 10 , statistically insignificant difference in wound contraction compared to the controls in the P.vulgare group was observed $(p<0.2)$ (Figure 1). No local or systematic side effects were observed macroscopically during the application of the extract. 

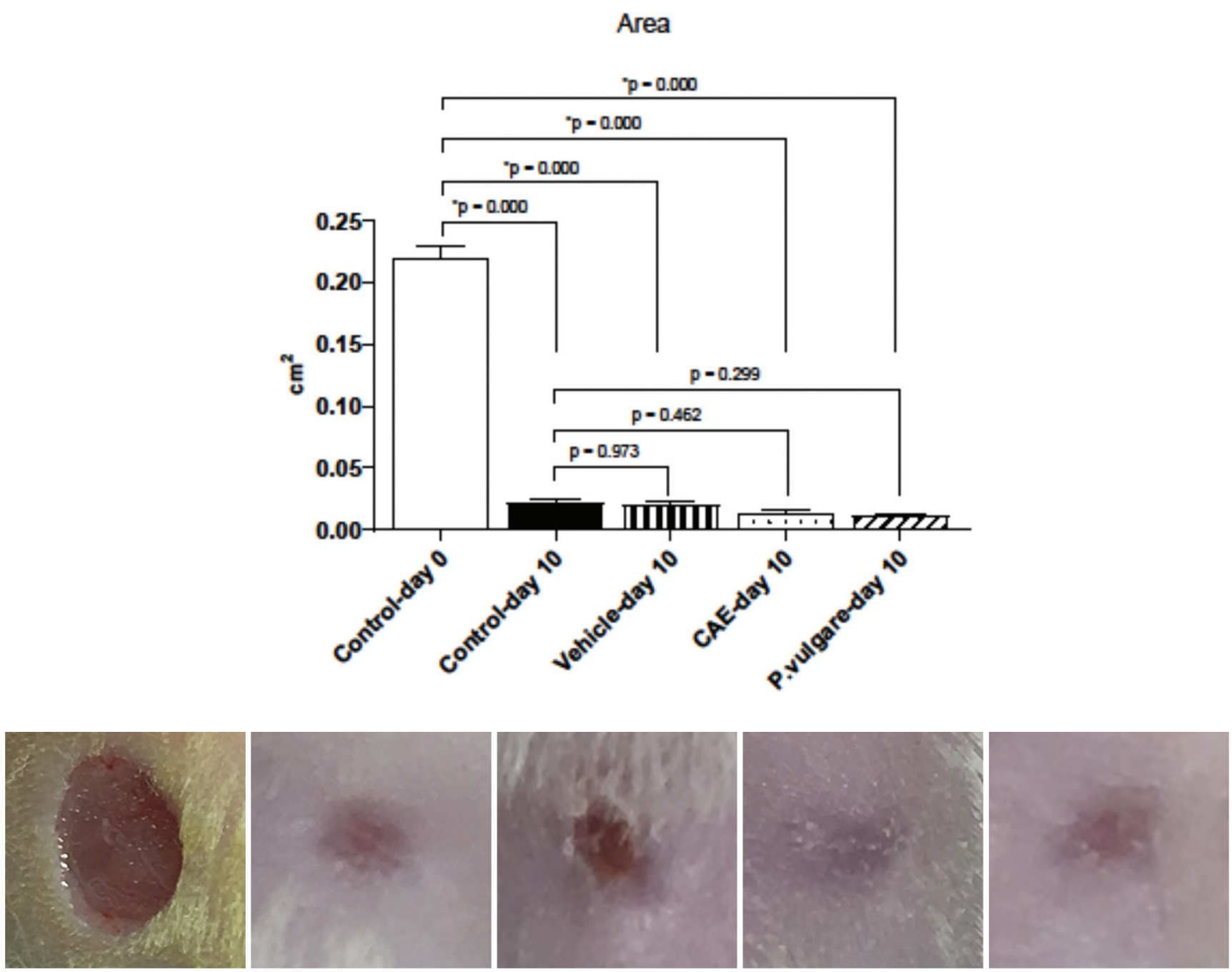

Figure 1. Macroscopic wound healing and healing percentage of wound area in each group (Control, vehicle, CAE, P. vulgare groups).

\section{Histology of wound healing}

Histological evaluation (H\&E evaluation and immunohistochemical (VEGF, PDGF, and collagen) were appraised separately. Histopathologically, H\&E (Figure 2 A, B, C, D) and immunohistochemical staining were shown in Figure $3 \mathrm{D}$. CAE $(p<0.05)$ and P. vulgare extract $(p<0.05)$ groups were observed to be more effective than the control and vehicle groups in terms of new vascular organization, epidermal and granulation tissue organization (Figure 2 E, F, G). PDGF, VEGF, and collagen immunohistochemical staining was stronger in the P.vulgare extract and CAE groups compared to the control and vehicle groups (Figure $3 \mathrm{D}$ ). In the P.vulgare and CAE group, PDGF staining intensity was stronger than the control and vehicle groups, although not statistically significant (Figure 3A), but VEGF and collagen staining in the P.vulgare group were not different from the control group (Figure $3 \mathrm{~B}, \mathrm{C}$ ).

\section{DISCUSSION}

Plants rich in antioxidant compounds are used for their wound-healing and anti-aging properties. Also, free oxygen radicals play an important role in apoptosis and cell proliferation mechanisms. 

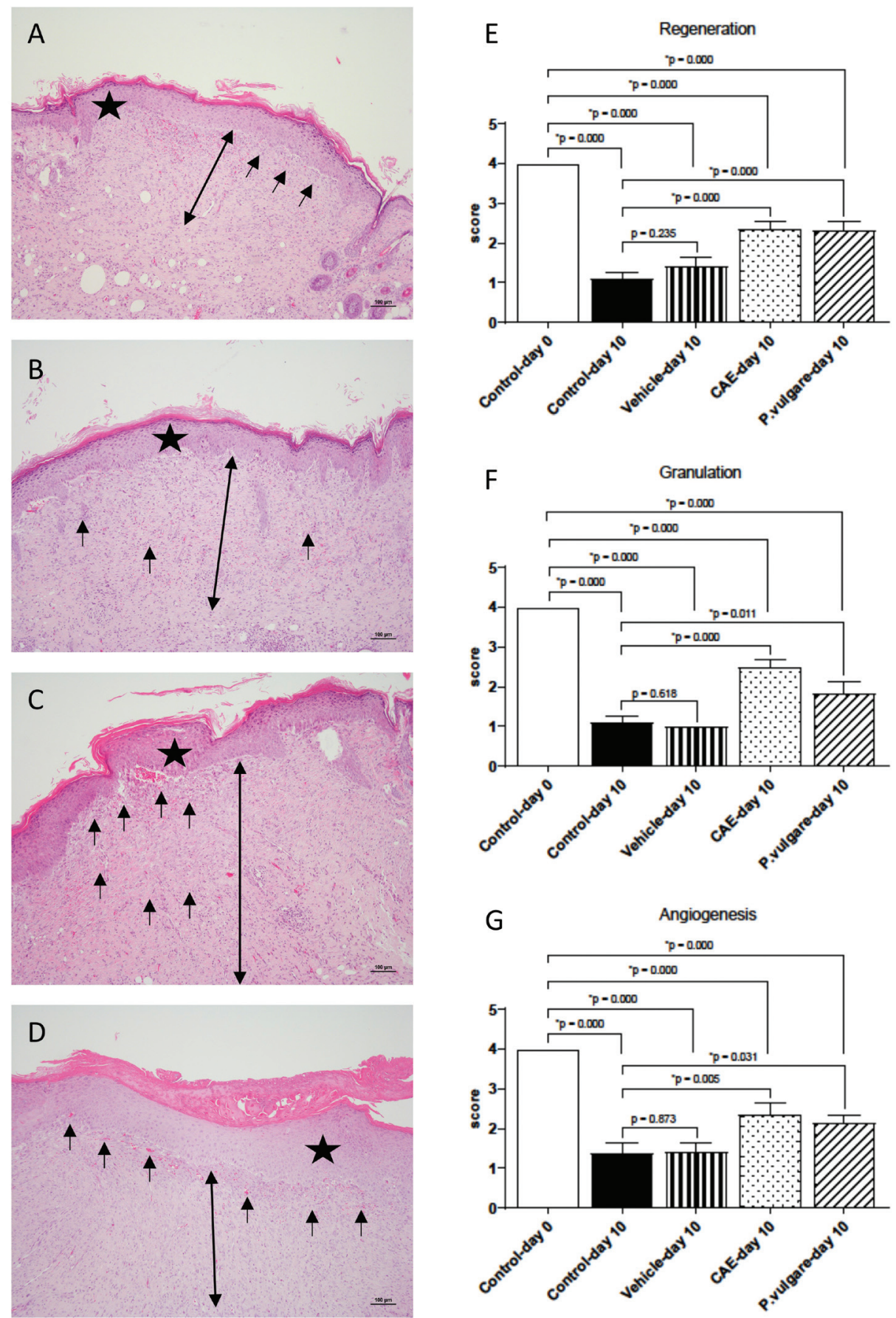

Figure 2. Histopathological view of injured tissues of the control (A), vehicle gel (B), CAE (C) and P.vulgare (D) extract gel on 10th day after wound incision (Original magnification X10). E, F, G; Histological scores of epidermal-dermal regeneration, granulation tissue thickness and angiogenesis of control, vehicle gel, CAE, P. vulgare groups. Statistically significant as compared to control; $P<\mathbf{0 . 0 5}$. Values are presented as the mean \pm SEM. The scale bars represent 100 um for figure. *: Epidermal regeneration, $\rightarrow$ : Angiogenesis, blood vessels, $\leftrightarrow$ : Granulation formation.

Studies have shown that topical application of antioxidant-containing compounds will be beneficial for wound healing and protecting tissues from oxidative damage $\mathrm{e}^{7,22}$. In our experiments, the antioxidant effect of the extract was revealed, and the antioxidant capacity was thought to be 
A

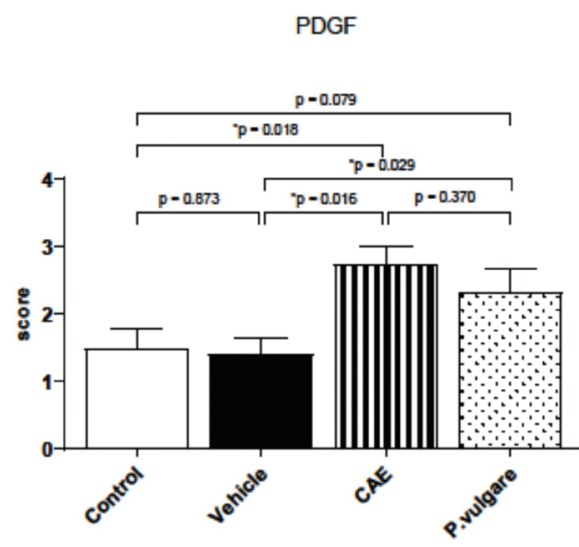

B

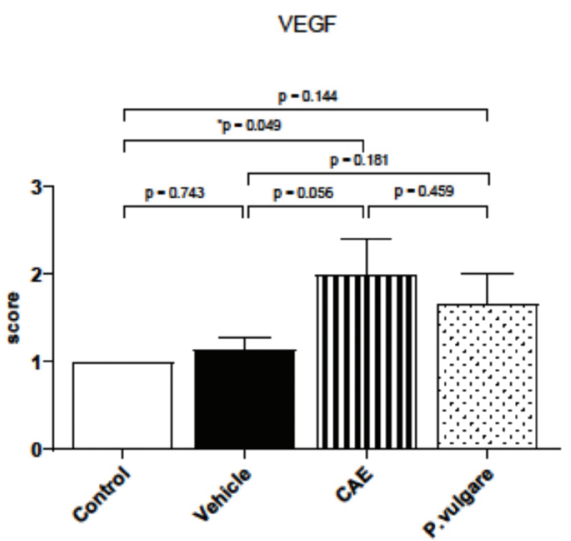

C

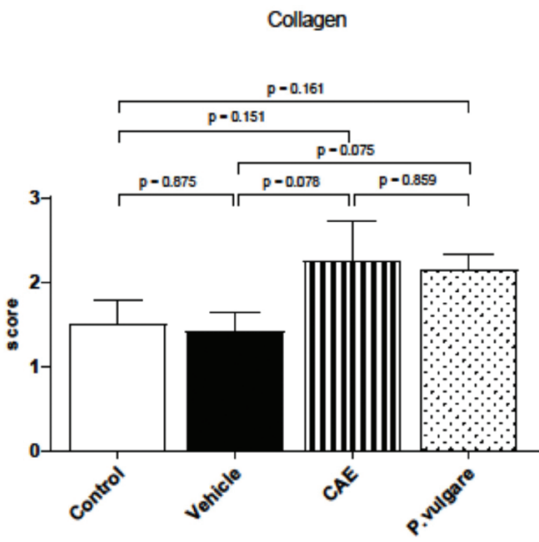

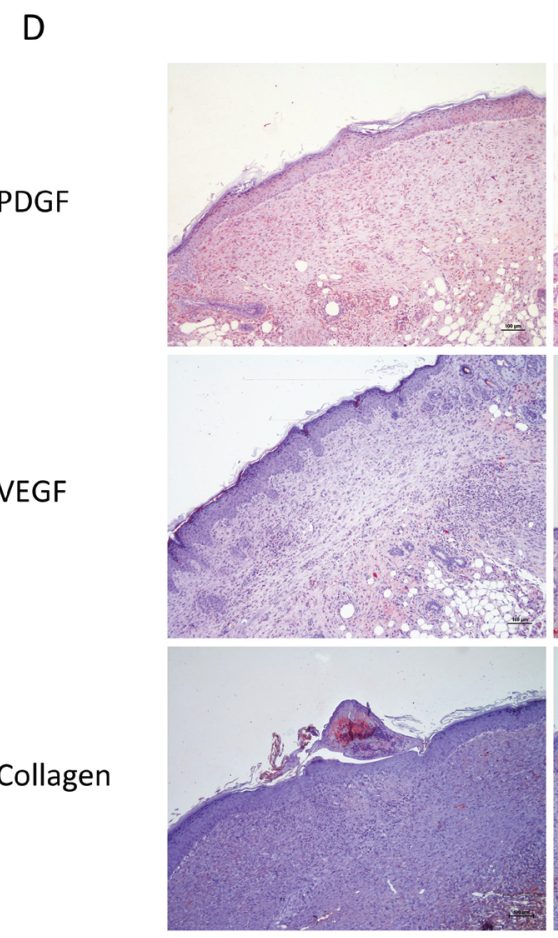

Control

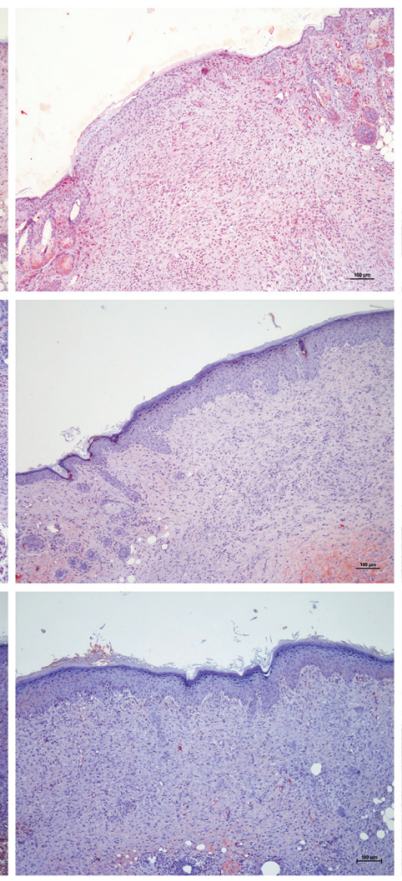

Vehicle

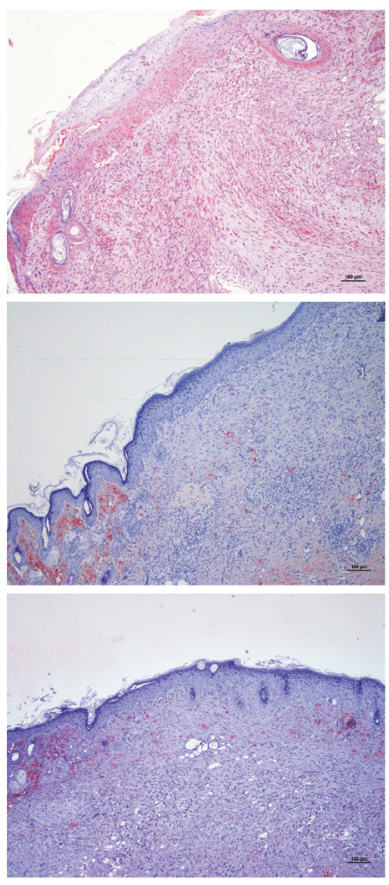

CAE

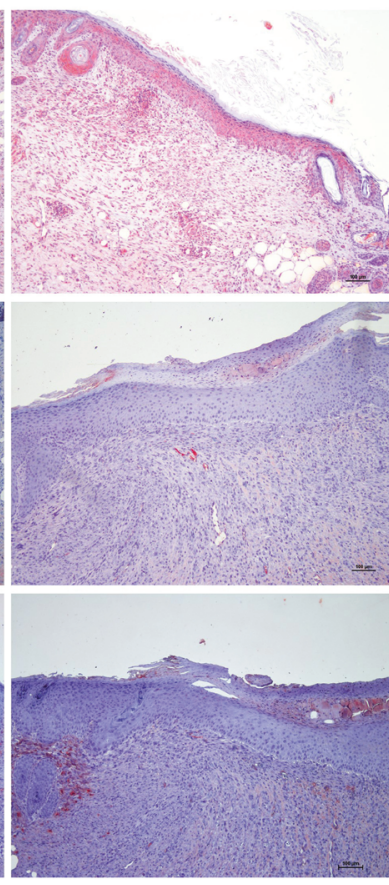

P.vulgare

Figure 3. A, B, C, Comparison of immunohistochemistry collagen, PDGF and VEGF wound healing Scores among groups. Statistically significant as compared to control; $P<0.05\left(^{*}\right)$. Values are presented as the mean $\pm S E M$. $D$, Histopathological view of injured tissues of the untreated (control), vehicle, P.vulgare and CAE groups on 10th day after wound incision (Original magnification X10).

effective in wound healing. In our study, the antimicrobial activity of P. vulgare extract was shown. Prevention of microorganisms from multiplying in wound care and the healing process are an important parameters ${ }^{23}$. Therefore, the antibacterial effect of the extract against various microorganisms found in the human skin flora was investigated for this purpose in our study.

The skin is the largest organ in human body, which 
acts as the defensive set across physical damage, pathogens, fluid loss, and maintain the body homeostasis $^{24}$. Thus, even a small breakage can impact the health of the individuals. Wound healing is a complex process, although some parts are explained in detail, the rest still need to be explained. The wound healing process is comprised of three different phases. The first is the inflammatory stage that leukocytes migrate to the wound area, followed by the proliferation phase, which includes reepithelization, angiogenesis, and granulation tissue formation. The proliferation phase is important and it starts after three days. The proliferation phase consists different stages to protect the barrier function of the tissue and provide protection against fluid loss and bacterial entry. The last stage is the restructuring phase when the wound is finally contracted ${ }^{7}$. Multiple studies have shown that essential oils of various medicinal plants increase the wound healing with active ingredients from aromatic plants and fruits ${ }^{7,25}$. In this study, we observed that P. vulgare increased wound healing, especially by increasing PDGF. In general, angiogenesis impacts embryonic development and wound healing. In our study, it was determined that CAE and P. vulgare extracts significantly effect neovascularization, epidermal organization, and granulation tissue formation compared to the control and vehicle groups. Besides, neovascularization is essential for wound healing ${ }^{4,7}$. Epidermal organization, granulation tissue formation, and revascularization are the critical agents of wound healing. Formation of organized granulation tissue, with the formation of capillary vessels are important criteria in wound healing. During healing process of the wounds, the granulation tissue acts to protect against infections and epithelial cells migrate to this area ${ }^{26}$. In our study, significant epidermal organization was observed in CAE and P.vulgare groups compared to the control and vehicle groups. The TGFbeta, PDGF, fibroblast growth factor (FGF), epidermal growth factor (EGF), and VEGF decreased in chronic wounds. In addition, grade of tumor necrosis factor-alfa (TNF-alfa), interleukins (IL) 1 and
6 decreased in chronic wounds ${ }^{27}$. it was shown that the expression of PDGF in CAE and P. vulgare groups was increased relative to that of control and vehicle groups. Angiogenesis improves fibroblast activity and feeding in the wound area. Fibroblast activity contributes to the formation of granulation tissue. Reactive oxygen specimen (ROS) in wounds decreases fibroblast proliferation and migration; and accordingly, collagen synthesis decreases ${ }^{28}$. In our study collagen staining of $P$. vulgare was not different from the control group probably for this reason. Angiogenesis scores of P. vulgare group were not different from the control group.

We observed that P.vulgare enhances skin wound healing. There were marked increases in epidermal regeneration and granulation tissue in the P.vulgare and CAE groups compared to the control group. In light of all this information, P. vulgare extract may be a new option in wound healing because of having similar properties of CAE.

\section{REFERENCES}

1. Rieger S, Zhao H, Martin P, Abe K, Lisse TS. The role of nuclear hormone receptors in cutaneous wound repair. Cell Biochem Funct. 2015;33:1-13. [CrossRef]

2. Siafaka PI, Zisi AP, Exindari MK, Karantas ID, Bikiaris DN. Porous dressings of modified chitosan with poly(2-hydroxyethyl acrylate) for topical wound delivery of levofloxacin. Carbohydr Polym. 2016;143:90-9. [CrossRef]

3. Ustundag Okur N, Hokenek N, Okur ME, et al. An alternative approach to wound healing field; new composite films from natural polymers for mupirocin dermal delivery. Saudi Pharm J. 2019;27:738-52. [CrossRef]

4. Okur ME, Ayla S, Cicek Polat D, Gunal MY, Yoltas A, Biceroglu O. Novel insight into wound healing properties of methanol extract of Capparis ovata Desf. var. palaestina Zohary fruits. J Pharm Pharmacol. 2018;70:1401-13. [CrossRef]

5. Shedoeva A, Leavesley D, Upton Z, Fan C. Wound Healing and the Use of Medicinal Plants. Evid Based Complement Alternat Med. 2019;2019:2684108. [CrossRef]

6. Dorai AA. Wound care with traditional, complementary and alternative medicine. Indian J Plast Surg. 2012;45:418-24. [CrossRef]

7. Ayla S, Okur ME, Gunal MY, et al. Wound healing effects of methanol extract of Laurocerasus officinalis roem. Biotech Histochem. 2019;94:180-8. [CrossRef]

8. Kim SH, Dubois GE. Natural high potency sweeteners. 1991:116-85. [CrossRef]

9. Yamada H, Nishizawa M, Katayama C. Osladin, a sweet 
princple of polypodium vulgare. Structure revision. Tetrahedron Letters. 1992;33:4009-10. [CrossRef]

10. Abbet C, Mayor R, Roguet D, Spichiger R, Hamburger $\mathrm{M}$, Potterat $\mathrm{O}$. Ethnobotanical survey on wild alpine food plants in Lower and Central Valais (Switzerland). J Ethnopharmacol. 2014;151:624-34. [CrossRef]

11. Delitheos A, Tiligada E, Yannitsaros A, Bazos I. Antiphage activity in extracts of plants growing in Greece. Phytomedicine. 1997;4:117-24. [CrossRef]

12. Mannan A, Khan RA, Asif M. Pharmacodynamic studies on Polypodium vulgare (Linn.). Indian J Exp Biol. 1989;27:556-60.

13. Saeedi M, Babaie K, Karimpour-Razkenari E, et al. In vitro cholinesterase inhibitory activity of some plants used in Iranian traditional medicine. Nat Prod Res. 2017;31:2690-4. [CrossRef]

14. Glensk M, Tichaczek-Goska D, Sroda-Pomianek K, Wlodarczyk M, Wesolowski CA, Wojnicz D. Differing antibacterial and antibiofilm properties of Polypodium vulgare L. Rhizome aqueous extract and one of its purified active ingredients-osladin. J Herb Med. 2019;17-8. [CrossRef]

15. Glensk M, Dudek MK, Ciach M, Wlodarczyk M. Isolation and structural determination of flavan-3-ol derivatives from the Polypodium vulgare L. rhizomes water extract. Nat Prod Res. 2019:1-10. [CrossRef]

16. Yao $\mathrm{CH}$, Yeh JY, Chen YS, Li MH, Huang $\mathrm{CH}$. Woundhealing effect of electrospun gelatin nanofibres containing Centella asiatica extract in a rat model. J Tissue Eng Regen Med. 2017;11:905-15. [CrossRef]

17. Blois MS. Antioxidant Determinations by the Use of a Stable Free Radical. Nature. 1958;181:1199-200. [CrossRef]

18. Re R, Pellegrini N, Proteggente A, Pannala A, Yang M, Rice-Evans C. Antioxidant activity applying an improved ABTS radical cation decolorization assay. Free Radical Biology and Medicine. 1999;26:1231-7. [CrossRef]

19. Gunal MY, Okcu Heper A, Zaloglu N. The Effects of Topi- cal Carvacrol Application on Wound Healing Process in Male Rats. Pharmacognosy Journal 6:10-3. [CrossRef]

20. Galeano M, Altavilla D, Bitto A, et al. Recombinant human erythropoietin improves angiogenesis and wound healing in experimental burn wounds. Crit Care Med. 2006;34:1139-46. [CrossRef]

21. Tuzun F, Gencpinar P, Ozbal S, et al. Neuroprotective effect of neotrofin in a neonatal rat model of periventricular leukomalacia. Neurosci Lett. 2012;520:6-10. [CrossRef]

22. Kumar B, Vijayakumar M, Govindarajan R, Pushpangadan P. Ethnopharmacological approaches to wound healing-exploring medicinal plants of India. J Ethnopharmacol. 2007;114:103-13. [CrossRef]

23. Kaplan SL, Hulten KG, Gonzalez BE, et al. Three-year surveillance of community-acquired Staphylococcus aureus infections in children. Clin Infect Dis. 2005;40:1785-91. [CrossRef]

24. Cañedo-Dorantes L, Cañedo-Ayala M. Skin Acute Wound Healing: A Comprehensive Review. International Journal of Inflammation. 2019;2019:1-15. [CrossRef]

25. Cavalcanti JM, Leal-Cardoso JH, Diniz LR, et al. The essential oil of Croton zehntneri and trans-anethole improves cutaneous wound healing. J Ethnopharmacol. 2012;144:240-7. [CrossRef]

26. Somboonwong J, Kankaisre M, Tantisira B, Tantisira MH. Wound healing activities of different extracts of Centella asiatica in incision and burn wound models: an experimental animal study. BMC Complement Altern Med. 2012;12:103. [CrossRef]

27. Han G, Ceilley R. Chronic Wound Healing: A Review of Current Management and Treatments. Adv Ther. 2017;34:599-610. [CrossRef]

28. Zeng Z, Zhu BH. Arnebin-1 promotes the angiogenesis of human umbilical vein endothelial cells and accelerates the wound healing process in diabetic rats. J Ethnopharmacol. 2014;154:653-62. [CrossRef] 